\title{
Efektivitas Penggunaan Media Pembelajaran I-Spring Presenter Untuk Meningkatkan Kemampuan Tahfizh Al-Qur'an Di Pesantren Persis Tarogong
}

\author{
Dede Ishak ${ }^{1}$, Uman Suherman ${ }^{2}$, Maskur $^{3}$ \\ ${ }^{1,3}$ Magister Teknologi Pendidikan, Sekolah Pascasarjana, Institut Pendidikan Indonesia, Garut \\ dedeishak@institutpendidikan.ac.id ${ }^{1}$, umansuherman@upi.edu $^{2}$
}

\begin{abstract}
Abstrak
Penelitian ini bertujuan untuk mengetahui: 1) Perbedaan kemampuan menghafal Al-Qur'an antara menggunakan media pembelajaran I-Spring Presenter dan menggunakan metode konvensional, 2) Peningkatan kemampuan tahfizh Al-Qur'an pada penggunaan media pembelajaran I-Spring Presenter, dan 3) Efektivitas penggunaan media pembelajaran I-Spring Presenter berdasarkan aspek-aspek tahfizh Al-Qur'an. Sedangkan metode yang digunakan dalam penelitian ini adalah mengarah pada teknik korelasional dan dapat digolongkan ke dalam jenis penelitian eksperimen dan penelitian korelasional, dimana melalui penelitian ini diharapkan diperoleh gambaran tentang variabel-variabel penelitian. untuk menguji keefektifan penelitian ini menggunakan metode eksperimen dengan desain Quasi Experiment Design. Dengan demikian hasil penelitian yang diperoleh menunjukan bahwa: 1) Terdapat perbedaan kemampuan dalam menghafal Al-Qur'an, antara tahfizh Al-Qur'an menggunakan media pembelajaran ISpring Presenter dengan menggunakan metode konvensional rata-rata pada kategori sedang dengan hasil lebih baik pada penggunaan I-Spring Presenter. 2) Terdapat peningkatan kemampuan tahfizh Al-Qur'an dengan menggunakan media pembelajaran I-Spring Presenter pada kategori sedang sebanyak $89 \%$. 3) Penggunaan media pembelajaran $I$ Spring Presenter mampu meningkatkan kemampuan tahfizh Al-Qur'an secara efektif pada aspek: kelancaran, tajwid, dan kefashihan. Dari hasil tersebut dapat direkomendasikan sebagai berikut: 1) Diharapkan pihak pesantren dapat menggunakan media I-Spring Presenter pada program tahfizh Al-Quran peserta didik, pihak pesantren dapat memfasilitasi ketersediaan sarana dan prasarana pembelajaran tahfizh Al-Quran. 2) Penggunaan media pembelajaran I-Spring presenter terbukti lebih baik dalam meningkatkan kemampuan tahfzh Al-Qur'an sehingga media pembelajaran ini dapat digunakan oleh pendidik dan peserta didik dalam program tahfizh di Pesantren dan 3) Penggunaan media pembelajaran I-Spring presenter terbukti efektif untuk meningkatkan kemampuan tahfizh AlQuran seluruh peserta didik pada tiga aspek sehingga dapat dikembangkan metode yang lebih baik lagi oleh peneliti selanjutnya pada aspek makhorijul huruf, shifatul huruf dan konsistensi hafalan Al-Qur'an.
\end{abstract}

Kata Kunci: Media Pembelajaran I-Spring Presenter, Kemampuan Tahfizh Al-Qur'an

\begin{abstract}
The purpose of this research is to find out: 1) The difference in the ability to memorize the Qur'an between using ISpring Presenter learning media and using conventional methods, 2) Increasing the ability of Al-Qur'an tahfizh on the use of I-Spring Presenter learning media, and 3) Effectiveness of the use of learning media I -Spring Presenter based on aspects of the Qur'an's tahfizh. While the method used in this study is to lead to correlational techniques and can be classified into types of experimental research and correlational research, through which this research is expected to obtain an overview of the research variables. to test the effectiveness of this study using an experimental method with a Quasi Experiment Design. Thus the research results obtained indicate that: 1) There is a difference in the ability to memorize the Al-Qur'an, between tahfizh Al-Qur'an using the I-Spring Presenter learning media using conventional methods on average in the medium category with better results on the use of I-Spring Presenter. 2) There is an increase in the ability of the Qur'an's tahfizh by using the medium of I-Spring Presenter learning in the medium category by 89\%.3) The use of the I-Spring Presenter learning media is able to effectively increase the ability of the Qur'an's tahfizh on aspects: fluency, recitation, and fluency. From these results it can be recommended as follows1) It is hoped that the pesantren can use the I-Spring Presenter media in the students' Al-Quran tahfizh program, the pesantren can facilitate the availability of facilities and infrastructure for Al-Quran tahfizh learning. 2) The use of the I-Spring learning media presenter is proven to be better in improving the ability of the Qur'anic tahfzh so that this learning media can be used by educators and students in the tahfizh program at Islamic Boarding Schools and 3) The use of the I-Spring learning media presenter has proven to be effective in improving the ability of Al-Quran tahfizh of all students on three aspects so that a better method can be developed by the next researcher on the aspects of makhorijul letters, shifatul letters and the consistency of memorizing the Qur'an.
\end{abstract}

Keywords: Learning Media I-Spring Presenter, Ability of Tahfizh Al-Qur'an 


\section{A. PENDAHULUAN}

\section{Latar Belakang Masalah}

Teknologi dan informasi saat ini berkembang sangat pesat bagaikan peluru yang sulit untuk dihentikan. Semua generasi dituntut untuk dapat menggunakan teknologi agar tidak tertinggal oleh zaman yang semakin modern. Pemanfaatan teknologi yang begitu luas akan membantu mempermudah segala aspek kehidupan. Seiring dengan perkembangan peradaban manusia dan kemajuan teknologi, maka saat ini dibutuhkan kemampuan untuk merespon tantangan perkembangan zaman tersebut.

Proses pendidikan menjadi sarana penting dalam upaya menciptakan generasi unggul melalui proses pembelajaran. Proses pembelajaran yang aktif dan kreatif dapat terwujud melalui penerapan teknologi pembelajaran. Penerapan teknologi pembelajaran dalam praktik kegiatan belajar mengajar ditujukan untuk dapat mewujudkan rancangan pembelajaran yang lebih rasional, lebih menarik, efektif dan efisien. Peserta didik dapat belajar lebih menyenangkan, lebih mudah, lebih cepat, dan lebih murah sehingga mampu menumbuhkan ketertarikan pada hal-hal yang dipelajarinya Dengan penerapan teknologi pembelajaran juga diharapkan pelaksanaan evaluasi proses pembelajaran dan hasil belajar peserta didik lebih objektif. Pencapaian target belajar dalam mata pelajaran tahfizh (hafalan) Al- Qur'an merupakan proses pembelajaran yang membutuhkan perpaduan antara potensi peserta didik dan pendidik serta ditunjang penggunaan media pembelajaran yang efektif.

Al Qur'an bagi umat Islam memiliki peran dan kegunaan yang sangat penting dalam kehidupan sehari hari salah satu diantaranya sebagai sumber ilmu pengetahuan dan sebagai safaat bagi para pembacanya dan para penghafalnya. Pendidikan Al-Quran harus ditanamkan sejak dini yaitu melalui pembelajaran Tahfizh Al-Qur'an yang meliputi; menghafal mempelajari dan mengamalkan isi dari Al Qur'an. Tahfizh AlQur'an merupakan faktor penting dalam sejarah kehidupan manusia, juga memperbanyak lembaga-lembaga Al-Qur'an merupakan suatu usaha diantara sekian usaha yang dapat dilakukan dalam rangka menjaga Kemutawatiran Al-Qur'an dan sebagai sarana untuk meningkatkan kualitas umat. Lembagalembaga pendidikan yang memberikan perhatian khusus kepada program pendidikan Al Qur'an yang menfokuskan diri pada menghafal Al-Qur'an yaitu di Madrasah Aliyah Pesantren Persatuan Islam Tarogong Garut

Madrasah Aliyah Pesantren Persatuan Islam Tarogong salah satu lembaga yang disiapkan bagi para generasi Islam untuk mencintai Al-Qur'an dan mengamalkannya dengan mendidik peserta didiknya hafal AlQur'an. Metoda pembelajaran berbasis multimedia sebetulnya telah diadopsi oleh Pesantren Persatuan Islam Tarogong Garut. Diantara visi dan misinya adalah terwujudnya Pesantren sebagai miniature masyarakat Islami dan lembaga pendidikan unggulan, juga membina insan berakhlakul-karimah yang tafaqquh fiddin dan menguasai iptek.

Al-Qur'an selain dibaca dan direnungkan, juga perlu untuk dihafal, dipindahkan dari tulisan ke dalam dada, karena hal ini merupakan ciri khas orang-orang yang diberi ilmu, juga sebagai tolok ukur keimanan dalam hati seseorang. Menurut Sa'adulloh (2008:17), Rasulullah SAW bersabda, yang artinya:

"Sesungguhnya orang yang di dalam dadanya tidak terdapat sebagian ayat daripada AlQur'an, bagaikan rumah yang tidak berpenghuni." (HR. At-Tirmidzi).

Pencapaian target belajar dalam mata pelajaran tahfizh Al-Qur'an di Madrasah Aliyah Pesantren Persatuan Islam Tarogong Garut merupakan proses pembelajaran yang membutuhkan perpaduan antara potensi peserta didik dan pendidik serta ditunjang penggunaan media pembelajaran yang efektif. Pelajaran tahfizh Al-Qur'an membutuhkan stimulus visual untuk mengingat kembali ayat per ayat. Pelajaran tahfizh Qur'an juga 
membutuhkan stimulus auditorial untuk memutar kembali dan mengulangi bagian-bagian ayat yang belum dikuasai siswa. Sehingga apabila pembelajaran tahfizh Al- Qur'an dilakukan dengan audiovisual maka diharapkan belajar meningkat menjadi $50 \%$. Semakin banyak alat indera yang digunakan untuk menerima dan mengolah informasi semakin besar kemungkinan informasi tersebut dimengerti dan dapat dipertahankan dalam ingatan. Media merupakan salah satu cara atau upaya untuk memudahkan proses pembelajaran tahfizh Al-Qur'an dalam meningkatkan kemampuan hafalan, afektif ataupun ranah psikomotorik.

Fenomena masalah yang terjadi, penggunaan media pembelajaran berbasis teknologi masih minim digunakan dalam pembelajaran tahfizh Al-Qur'an di Madrasah Aliyah Pesantren Persatuan Islam Tarogong Garut. Hal ini dapat terlihat dari pendidik masih melakukan pembelajaran tahfizh Al-Qur'an secara konvensional. Pendidik melakukan pembelajaran dengan metode ceramah dan pengulangan ayat per ayat sehingga peserta didik banyak yang tidak fokus, merasa bosan, dan ada juga yang sulit menambah hafalan ayat baru. Pembelajaran tahfidz Al Qur'an yang telah berjalan selama ini belum mempunyai model yang tepat dan ditetapkan. Peserta didik menghafal AlQur'an dibimbing peserta didik secara langsung dengan cara materi hafalan dibaca oleh pendidik dan diberikan kepada peserta didik (penghafal) secara berulang-ulang hingga hafal, kemudian peserta didik yang telah hafal menyetorkan hafalannya kepada pendidik. Cara seperti ini menimbulkan kejenuhan dan tidak menarik perhatian peserta didik. Nilai yang dihasilkan dalam ujian pun bersifat stagnan dan masih ada peserta didik yang kemampuan tahfizh Al-Qur'an nya rendah. Alat penunjang multimedia pembelajaran sebetulnya telah tersedia di Pesantren seperti; laboratorium komputer, kaset /CD Alqur'an, infocus, sound sistem namun belum digunakan untuk pembelajaran tahfizh AlQur'an. Fasilitas ini dikoordinasi khusus oleh Bagian Lembaga Multimedia.

Mengacu pada berbagai permasalahan di atas, maka peneliti tertarik untuk melakukan penelitian yang berjudul " Efektivitas Penggunaan Media Pembelajaran I-Spring Presenter untuk Meningkatkan Kemampuan Tahfizh Al Qur'an di Pesantren Persatuan Islam Tarogong." (Quasi Eksperimen pada Peserta Didik Kelas XI Madrasah Aliyah Persis Tarogong Kabupaten Garut)

\section{B. Rumusan Masalah}

Rumusan masalah dalam penelitian ini adalah "Bagaimana efektivitas penggunaan media pembelajaran I-Spring Presenter dapat Meningkatkan Kemampuan Tahfizh Al-Qur'an di Pesantren Persatuan Islam Tarogong?"

Berdasarkan rumusan masalah di atas, maka masalah dalam penelitian ini dapat diuraikan menjadi pertanyaan penelitian berikut ini:

1. Apakah terdapat perbedaan kemampuan tahfizh Al-Qur'an peserta didik antara menggunakan media pembelajaran I-Spring Presenter dan menggunakan metode konvensional?

2. Apakah terdapat peningkatan kemampuan tahfizh Al-Qur'an peserta didik pada penggunaan media pembelajaran I-Spring Presenter di Pesantren Persis Tarogong?

3. Bagaimana efektivitas penggunaan media pembelajaran I-Spring Presenter berdasarkan Aspek-Aspek Tahfizh AlQur'an di Pesantren Persis Tarogong?

\section{Tujuan Penelitian}

Berdasarkan rumusan masalah di atas, maka tujuan umum penelitian ini adalah untuk mengetahui efektivitas penggunaan media pembelajaran I-Spring Presenter dapat meningkatkan kemampuan tahfizh Al-Qur'an di Pesantren Islam Tarogong. Adapun tujuan khusus penelitian ini adalah sebagai berikut:

1. Untuk mengetahui perbedaan kemampuan tahfizh Al-Qur'an peserta didik antara 
menggunakan media pembelajaran I-Spring Presenter dan menggunakan metode konvensional di Pesantren Persis Tarogong.

2. Untuk mengetahui peningkatan kemampuan tahfizh Al-Qur'an peserta didik pada penggunaan media pembelajaran I-Spring Presenter di Pesantren Persis Tarogong.

3. Untuk mengetahui efektivitas penggunaan media pembelajaran $I$ Spring Presenter berdasarkan Aspek-Aspek Tahfizh Al-Qur'an di Pesantren Persis Tarogong.

\section{B. KAJIAN LITERATUR}

\section{Media Pembelajaran dengan I-Spring Presenter}

\section{Pengertian Media Pembelajaran}

Kata media merupakan bentuk jamak dari kata medium. Medium dapat didefinisikan sebagai perantara atau pengantar terjadinya komunikasi dari pengirim menuju penerima (Sadiman, 2007: 7). Menurut Daryanto (2012), media merupakan salah satu komponen komunikasi yaaitu sebagai pembawa pesan dari komunikator menuju komunikan. AECT (Assosiation of Education and Communication Technology) memberikan batasan tentang media sebagai segala bentuk dan saluran yang digunakan untuk menyampaikan pesan atau informasi. Sedangkan menurut Arsyad (2013:3) pengertian media dalam proses belajar mengajar cenderung diartikan sebagai alat-alat grafis, fotografis atau elektronis untuk menangkap, memproses dan menyusun kembali informasi visual atau verbal.

Ciri gaya belajar visual adalah: (a) teliti terhadap yang detail, (b) mengingat dengan mudah apa yang dilihat, (c) mempunyai masalah dengan instruksi lisan, (d) tidak mudah terganggu dengan suara gaduh, (e) pembaca cepat dan tekun, (f) lebih suka membaca daripada dibacakan, (g) lebih suka metode demonstrasi daripada ceramah, (h) bila menyampaikan gagasan sulit memilih kata, (i) rapi dan teratur, (j) penampilan sangat penting.

Ciri gaya belajar auditorial adalah: (a) bicara pada diri sendiri saat bekerja, (b) konsentrasi mudah terganggu dengan suara ribut, (c) senang suara keras ketika membaca, (d) sulit menulis tapi mudah bercerita, (e) pembicara yang fasih, (f) sulit belajar dalam suasana bising, (g) lebih suka musik daripada lukisan, (h) bicara dalam irama yang terpola, (i) lebih suka gurauan lisan daripada membaca buku humor, (j) mudah menirukan nada, irama dan warna suara.

Pada penelitian ini, peneliti menggunakan menggunakan metode penelitian eksperimen semu (quasi eksperimen) dengan pendekatan kuantitatif dan analisis korelasional, yang didasari oleh keinginan peneliti untuk menguji hipotesis dari suatu teori yang telah ada.

Penelitian dengan pendekatan kuantitatif adalah penelitian yang bersifat mengkonfirmasi antara teori dengan kenyataan yang ada dengan mendasarkan pada data ilmiah dalam bentuk angka atau numerik dan analisis menggunakan statistik (Sugiono, 2013:7). Tujuan penelitian kuantitatif adalah mengembangkan dan mengggunakan modelmodel matematis, teori dan hipotesis yang dikaitkan dengan fenomena alam. Penarikan kesimpulan pada pendekatan kuantitatif bersifat deduktif yaitu menarik kesimpulan dari sesuatu yang bersifat umum ke sesuatu yang bersifat khusus.

Alasan penelitian ini dilakukan dengan pendekatan kuantitatif adalah memungkinkan dilakukannya pencapaian data hasil penelitian secara nyata dalam bentuk angka sehingga memudahkan proses analisis dan penafsiran dengan menggunakan perhitungan statistik yang kemudian penafsirannya digunakan untuk mengungkap kemampuan tahfizh Al-Qur'an.

\section{METODOLOGI PENELITIAN}

Pada penelitian ini, peneliti menggunakan menggunakan metode penelitian eksperimen semu (quasi eksperimen) dengan pendekatan kuantitatif dan analisis 
korelasional, yang didasari oleh keinginan peneliti untuk menguji hipotesis dari suatu teori yang telah ada.

Penelitian dengan pendekatan kuantitatif adalah penelitian yang bersifat mengkonfirmasi antara teori dengan kenyataan yang ada dengan mendasarkan pada data ilmiah dalam bentuk angka atau numerik dan analisis menggunakan statistik (Sugiono, 2013:7). Tujuan penelitian kuantitatif adalah mengembangkan dan mengggunakan model-model matematis, teori dan hipotesis yang dikaitkan dengan fenomena alam. Penarikan kesimpulan pada pendekatan kuantitatif bersifat deduktif yaitu menarik kesimpulan dari sesuatu yang bersifat umum ke sesuatu yang bersifat khusus.

Alasan penelitian ini dilakukan dengan pendekatan kuantitatif adalah memungkinkan dilakukannya pencapaian data hasil penelitian secara nyata dalam bentuk angka sehingga memudahkan proses analisis dan penafsiran dengan menggunakan perhitungan statistik yang kemudian penafsirannya digunakan untuk mengungkap kemampuan tahfizh Al-Qur'an.

Sesuai dengan tujuan penelitian ini maka metode penelitian yang digunakan dalam penelitian ini mengarah pada teknik korelasional. Penelitian ini dapat digolongkan ke dalam jenis penelitian eksperimen dan korelasional, dimana melalui penelitian ini diharapkan diperoleh gambaran tentang variabelvariabel serta bagaimana hubungan antara variabel-variabel penelitian, apakah perubahan pada variabel pertama diikuti oleh perubahan pada variabel kedua. Keeratan hubungan antara variabel-variabel tersebut dinyatakan dalam bentuk koefisien korelasi.

Dalam penelitian ini yang ingin dilihat adalah Efektivitas Penggunaan Media Pembelajaran I-Spring Presenter untuk Meningkatkan Kemampuan Tahfizh Al- Qur'an di Pesantren Persis Tarogong. (Quasi Eksperimen pada
Peserta Didik Kelas XI Madrasah Aliyah Persis Tarogong Kabupaten Garut).

\section{HASIL PENELITIAN DAN PEMBAHASAN}

Setelah dilakukan penelitian mengenai penggunaan media pembelajaran I-Spring Presenter terhadap peningkatan kemampuan tahfizh (Hafalan) peserta didik pada surah ArRohmaan pada kelas eksperimen dan menggunakan metode konvensional pada kelas kontrol. Kemudian data yang diperoleh tersebut dideskripsikan dan dianalisis, sehingga diperoleh suatu kesimpulan berkenaan dengan hipotesis yang diajukan pada bab sebelumnya. Berikut ini adalah uraian hasil penelitiannya:

\section{Perbedaan kemampuan tahfizh Al- Qur'an peserta didik antara menggunakan media pembelajaran I- Spring Presenter dan menggunakan metode konvensional.}

Terdapat perbedaan kemampuan tahfizh Al-Qur'an peserta didik yang signifikan antara menggunakan media pembelajaran I-Spring Presenter rata-rata 0,47 (kategori sedang) dan metode konvensional rata-rata 0,37 (kategori sedang) dengan hasil yang lebih baik pada penggunaaan media pembelajaran I-Spring Presenter dibandingkan metode konvensional.

2. Peningkatan kemampuan tahfizh AlQur'an peserta didik pada penggunaan media pembelajaran I-Spring Presenter

Deskripsi peningkatan kemampuan tahfizh Al-Qur'an dapat disajikan sebagai berikut:

Pada kualitas peningkatan kemampuan tahfizh Al-Qur'an pada masing-masing kelas, kelas eksperimen dan kontrol terdapat pada peningkatan kategori tinggi memiliki persentase yang sama yaitu 9\%. Pada peningkatan kemampuan tahfizh Al-Qur'an kategori sedang, kelas eksperimen memiliki persentase $89 \%$ dan kelas kontrol memiliki persentase $60 \%$. Perbedaan peningkatan kemampuan tahfizh Al-Qur'an pada kategori sedang sebesar 29\%. Pada peningkatan kemampuan tahfizh Al-Qur'an kategori rendah, kelas kontrol memiliki persentase yang 
lebih besar yaitu $31 \%$ dibandingkan kelas eksperimen yaitu $3 \%$. Perbedaan peningkatan kemampuan tahfizh AlQur'an pada kategori rendah sebesar 28 $\%$.

Berdasarkan hasil penelitian ini menunjukkan bahwa peningkatan kemampuan tahfizh Al-Qur'an dengan menggunakan media pembelajaran $I$ Spring Presenter berada pada kategori sedang sebanyak $89 \%$, kategori rendah sebanyak $31 \%$ dan kategori tinggi sebanyak $9 \%$. Sehingga dapat disimpulkan bahwa peningkatan kemampuan tahfizh Al-Qur'an lebih baik dengan menggunakan media pembelajaran I-Spring Presenter.

\section{Efektivitas penggunaan media pembelajaran I-Spring Presenter berdasarkan Aspek-Aspek Tahfizh Al-Qur'an}

Sebelum melakukan perhitungan besarnya keefektifan penggunaan media pembelajaran I-Spring Presenter dalam meningkatkan kemampuan tahfizh AlQur'an, terlebih dahulu dilakukan uji prasyarat. Uji prasyarat yaitu menguji sebaran data atau uji normalitas data peningkatan tahfizh Al-Qur'an kedua kelas dengan menggunakan uji ShapiroWilk.

Dari hasil pengujian tersebut, kelas eksperimen diperoleh nilai statistik uji sebesar 0,759 dengan nilai Sig. = 0,000; sedangkan pada kelas kontrol diperoleh nilai statistik uji sebesar 0,967 dengan nilai Sig. $=0,372$. Sebaran data dikatakan berdistribusi normal, jika nilai Sig. $>\alpha$. Dalam penelitian ini nilai $\alpha$ yang digunakan sebesar 0,05 ; sehingga dapat disimpulkan bahwa sebaran data peningkatan kelas eksperimen tidak berdistribusi normal, sedangkan kelas kontrol berdistribusi normal.

Untuk mengetahui ada tidaknya perbedaan peningkatan antara kelas eksperimen dengan kelas kontrol digunakan uji U-Mann Whitney melalui program SPSS versi 18. Pasangan hipotesis nol $\left(\mathrm{H}_{0}\right)$ dan hipotesis alternatif $\left(\mathrm{H}_{\mathrm{a}}\right)$ adalah sebagai berikut ini.

$\mathrm{H}_{0}$ : Tidak ada perbedaan peningkatan antara kelas eksperimen dengan kelas kontrol.

$\mathrm{H}_{\mathrm{a}}$ : Terdapat perbedaan peningkatan antara kelas eksperimen dengan kelas kontrol. Kriteria pengujian hipotesis adalah jika nilai probabilitas atau signifikansi (Sig.) lebih besar dari $\alpha=0,05$ maka Ho diterima. Dengan kata lain, peningkatan kelas eksperimen sama dengan kelas kontrol atau ditafsirkan tidak memiliki perbedaan yang berarti.

Pada bagian pertama, diperoleh deskripsi uji U-Mann Whitney bahwa rata-rata ranking dari kelas eksperimen dan kelas kontrol berturut-turut sebesar 42,17 dan 28,83 dengan jumlah ranking berturut-turut 1476,00 dan 1009,00. Hasil pengujian dengan uji U-Mann Whitney diperlihatkan pada tabel bagian kedua; yang menghasilkan nilai 379,000 dan Zhitung sebesar -2,744; adapun nilai Asymp. Sig. (2-tailed) sebesar 0,006. Karena nilai Asymp. Sig. (2-tailed) ini lebih kecil dari $\alpha=0,05$ maka keputusannya adalah $\mathrm{H}_{\mathrm{o}}$ ditolak dan $\mathrm{H}_{\mathrm{a}}$ diterima. Jadi dapat disimpulkan bahwa, terdapat perbedaan yang signifikasi antara peningkatan kelas eksperimen dengan kelas kontrol. Hal ini berarti bahwa peningkatan yang dialami peserta didik kelas eksperimen lebih baik daripada kelas kontrol sebanyak 78 ayat yang dihafalkan dan 4 halaman dalam AlQur'an.

Dari hasil pengujian hipotesis di atas, secara umum diketahui bahwa penggunaan media pembelajaran I-Spring Presenter efektif dalam meningkatkan kemampuan tahfizh AlQur'an peserta didik. Untuk mengetahui apakah berlaku secara khusus pada aspek: 1) Kelancaran dalam menghafal Al- Qur'an; 2) Kesesuaian bacaan dengan Makharijul Huruf (Tempat Keluarnya Huruf); 3) Kesesuaian bacaan dengan Shifatul huruf; 4) Kesesuaian bacaan dengan kaidah ilmu tajwid; 5) Kefasihan; dan 6) Konsistensi (Itqon), maka perlu dilakukan pula pengujian statistika.

Berdasarkan pengujian perbedaan kemampuan tahfizh Al-Qur'an berdasarkan aspeknya, dapat dijelaskan sebagai berikut: 
1. Pada aspek kelancaran hafalan AlQur'an, peserta didik kelas eksperimen, kelancaran hafalan nya lebih baik daripada peserta didik kelas kontrol;

2. Pada aspek Makhrojul Huruf hafalan Al-Qur'an, tidak menunjukkan adanya perbedaan kemampuan Makhrojul Huruf antara peserta didik kelas eksperimen dan peserta didik kelas kontrol;

3. Pada aspek Shifatul Huruf hafalan Al-Qur'an, tidak menunjukkan adanya perbedaan kemampuan Shifatul Huruf antara peserta didik kelas eksperimen dan peserta didik kelas kontrol;

4. Pada aspek tajwid hafalan AlQur'an, peserta didik kelas eksperimen, tajwid hafalan nya lebih baik daripada peserta didik kelas kontrol;

5. Pada aspek kefashihan hafalan AlQur'an, peserta didik kelas eksperimen, kefashihan hafalan nya lebih baik daripada peserta didik kelas kontrol;

6. Pada aspek konsistensi hafalan AlQur'an, tidak menunjukkan adanya perbedaan konsistensi hafalan antara peserta didik kelas eksperimen dan peserta didik kelas kontrol.

Berdasarkan hasil pengujian hipotesis berdasarkan aspek kemampuan tahfizh Al-Quran, maka dapat disimpulkan bahwa efektivitas penggunaan media pembelajaran $I$ Spring Presenter dapat meningkatkan kemampuan tahfizh Al-Qur'an pada aspek: kelancaran, tajwid, dan kefashihan.

Penggunaan media pembelajaran I-Spring Presenter dalam tahfizh AlQur'an dalam penelitian ini dapat efektif pada beberapa aspek karena media ini memiliki berbagai keunggulan sebagaimana yang disampaikan Hermawan (2014:1) yaitu : 1) I-Spring Presenter bekerja sebagai add-ins
PowerPoint, sehingga menjadikan tampilan file Power Point ayat-ayat Al-Qur'an lebih menarik dan interaktif berbasis Flash dan dapat dibuka hampir di setiap komputer atau platform. 2) Pembuatannya yang mudah dan hasil output yang tidak membutuhkan kapasitas besar sehingga tidak memberatkan laptop atau komputer. 3) Dapat menyisipkan berbagai bentuk media, sehingga media pembelajaran yang dihasilkan akan lebih menarik dan mudah diingat, dimana media dalam media ini dapat merekam suara ayat-ayat Al-Qur'an dan sinkronisasi video presenter, menambahkan Flash dan video YouTube, mengimpor atau merekam audio ayat-ayat Al-Qur'an, menambahkan informasi terjemah Al-Qur'an dan dapat menambahkan gambar background slide yang bergerak serta membuat navigasi dan desain yang unik. 4) Mudah didistribusikan atau dikonvert dalam format flash tanpa harus membuatnya dari software adobe flash player, yang dapat digunakan dimanapun dan serta dapat dioptimalkan untuk dipublish di halaman web secara offline. Menurut Teori Conditioning Edwin Guthrie dijelaskan bahwa hubungan antara stimulus dan respon cenderung bersifat sementara. Oleh sebab itu, dalam kegiatan belajar peserta didik perlu sesering mungkin diberikan stimulus agar hubungan antara stimulus dan respon bersifat tetap.

\section{E. SIMPULAN DAN REKOMENDASI}

Penggunaan Media Pembelajaran ISpring Presenter dalam Meningkatkan Kemampuan Tahfizh Al Qur'an di Pesantren Persis Tarogong dapat ditarik simpulan sebagai berikut:

1. Terdapat perbedaan kemampuan tahfizh Al-Qur'an peserta didik yang signifikan antara menggunakan media pembelajaran I-Spring Presenter rata-rata 0,47 (kategori sedang) dan metode konvensional rata-rata 0,37 (kategori sedang) dengan hasil yang lebih baik pada penggunaaan media pembelajaran I-Spring Presenter dibandingkan metode konvensional.

2. Terdapat peningkatan kemampuan tahfizh Al-Qur'an peserta didik dengan menggunakan media pembelajaran I- 
Dede Ishak ${ }^{1}$, Uman Suherman ${ }^{2}$, Maskur $^{3 /} /$ Efektivitas Penggunaan Media Pembelajaran I-Spring Presenter Untuk Meningkatkan Kemampuan Tahfizh Al-Qur'an Di Pesantren Persis Tarogong

Spring Presenter pada kategori sedang sebanyak $89 \%$, kategori rendah sebanyak $31 \%$ dan kategori tinggi sebanyak $9 \%$.

3. Penggunaan media pembelajaran I-Spring Presenter mampu meningkatkan kemampuan tahfizh Al-Qur'an secara efektif pada aspek: kelancaran, tajwid, dan kefashihan.

Berdasarkan simpulan yang diperoleh, maka dapat direkomendasikan sebagai berikut:

1. Diharapkan pihak sekolah atau pesantren dapat menggunakan media pembelajaran I-Spring Presenter pada program tahfizh Al-Qur'an dibandingkan dengan metode konvensional serta pendidik lebih termotivasi dalam mengembangkan potensinya hingga memiliki peranan penting dalam meningkatkan kemampuan belajar dan mengajarkan Al-Quran kepada peserta didik secara profesional dan berkelanjutan. Pihak sekolah diharapkan dapat memfasilitasi ketersediaan sarana dan prasarana pembelajaran tahfizh $\mathrm{Al}$ Quran agar peserta didik bisa nyaman dan konsisten dalam mengikuti program tahfizh tersebut.

2. Penggunaan media pembelajaran $I$ Spring Presenter dalam penelitian ini terbukti lebih baik dalam meningkatkan kemampuan tahfzh AlQur'an sehingga media pembelajaran ini dapat digunakan oleh pendidik dan peserta didik dalam program tahfizh di Pesantren.

3. Penggunaan media pembelajaran ISpring Presenter dalam penelitian ini terbukti efektif untuk meningkatkan kemampuan tahfizh Al-Quran seluruh peserta didik pada tiga aspek sehingga dapat dikembangkan metode yang lebih baik lagi oleh peneliti selanjutnya pada aspek lainnya, yaitu makhorijul huruf, shifatul huruf dan konsistensi hafalan Al-Qur'an.

\section{F. REFERENSI}

Abd. Al-Baqi, (2012). Fuad.al-Mu'jam alMufahras li al-Fadhzal-Qur'analKarim. Indonesia: Maktabah Dahlan.

Ahmad, Aziz dkk. (2012). Al Qur'an Per Kata, Tajwid Warna Robbani. Jakarta Timur: PT. Surya Prisma Sinergi.

Ahsin (2003). Bimbingan Praktis Menghafal Al-Qur'an, Jakarta: Bumi Aksara.

Alfianyah, R. (2012) Penggunaan Media Pembelajaran I-Spring Presenter Untuk Meningkatkan Motivasi Belajar dan Hasil Belajar Pada Mata Kuliah Keperawatan Dasar Nutrisi http://ejournal.upi.edu/index.ph p/pedagogia/article/view/3886 diakses pada 8/2/2017

Al-Qur'an (2016). al-quran-digital-alkalam.html

Al-Ṭhabarī, (1412 H/1992). Jāmi'u al-Bayān fì Ta wōli al-Qur`ān. Beirut: Daarul KItab.

Aqib, Z. (2013). Model-Model, Media dan Strategi Pembelajaran Kontekstual (Inovatif).Bandung: Yrama Widya.

Arikunto, S. (2010). Prosedur Penelitian Suatu Pendekatan Praktik. Edisi revisi. Jakarta: PT. Rineka Cipta.

Arsyad, Azhar (2013).Media pembelajaran. Jakarta: PT Raja Grafindo Persada. (2011). Media pembelajaran. Jakarta: PT Raja Grafindo Persada.

Aunurrahman (2008). Belajar dan Pembelajaran. Bandung : Alfabeta.

Azwar, Saifuddin (2012), Metode Penelitian, Yogyakarta: Pustaka Pelajar.

Baduwailan, A.(2014).Cara Mudah dan Cepat Hafal Al-Qur;an.Solo: Kiswah Media

Baggerly, Jennifer (2002). Practical Technological Applications to Promote Pedagogical Principles and Active Learning in Counselor Education. Journal of Technology in Counseling. Vol 2_2.

Baharuddin (2012). Metode Pembelajaran Ilmu Tajwid dalam Meningkatkan Kemampuan Membaca Al-Qur'an Santri Pondok Pesantren Tahfizh Al- 
Dede Ishak ${ }^{1}$, Uman Suherman ${ }^{2}$, Maskur $^{3 /} /$ Efektivitas Penggunaan Media Pembelajaran I-Spring Presenter Untuk Meningkatkan Kemampuan Tahfizh Al-Qur'an Di Pesantren Persis Tarogong

Qur'an Al Imam'Ashim Makassar. Tesis, Makassar: Program Pascasarjana UIN Alauddin Makassar.

Chaplin, J.P. (2002). Kamus Lengkap Psikologi. Jakarta: P.T. Grafindo Persada

Dahar Ratna W (1988). Teori-Teori Belajar. Jakarta : Erlangga.

Damasari (2104). Pengembangan Media Pembelajaran iSpring Suite 6.0 Materi Teori

Daradjat, Zakiah (1990). Memahami Persoalan Remaja. Jakarta : Gunung Agung.

Darmawan, D. (2012). Inovasi Pendidikan, Pendekatan Praktik Teknologi Multimedia dan Pembelajaran Online. Bandung: PT Remaja Rosdakarya.

Daryanto. (2012). Media Pembelajaran. Bandung: PT. Sarana Tutorial Nurani Sejahtera.

(2013). Inovasi Pembelajaran Efektif, Bandung:Yrama Widya.

Departemen Pendidikan Nasional. (2003).Undang-Undang Nomor 20 Tahun 2003 Tentang Sistem Pendidikan Nasional, Jakarta : Depdiknas.

DePorter, Bobbi dan Hernacki, Mike. (2013). Quantum Learning: Membiasakan Belajar

Dinainda (2013). Makhorijul Huruf. Diakses pada 14 Agustus 2019. https://dinainda.wordpress.com/ 2013/02/28/makhorijul-huruftempat-keluar-huruf/

Fathoni, Dimyati (2000), Memilih Metode Menghafal Al-Qur'an Yang Baik dan Upaya Mencetak Huffazhul Qur'an Yang Sempurna, Mojokerto: Ringkasan untuk santri PP Bidayatul Bidayah.

Fuad, Abd. Al-Baqi (2001). al-Mu'jam al-Mufahras li al-Fadhz alQur`an al-Karim. Indonesia:
Maktabah Dahlan.

Hermawan, Hudiana. (2014). Modul Kuliah Pembuatan Multimedia Dengan Bantuan Software I-Spring Presenter.

Hernawati, Kuswari (2010). Modul Pelatihan I-Spring Presenter. Pelatihan Pembuatan Media Pembelajaran Interaktif dengan Perangkat Lunak ISpring Bagi Guru Sekolah Menengah. Yogyakarta: Laboratorium Komputer Jurdik Matematika FMIPA UNY.

Hidayatulloh. (2010). Menghafal Al-Qur'an dapat Tingkatkan Prestasi Akademis. Diakses pada 14 Agustus 2019 dari http://www.voa-

islam.com/lintasberita/hidayatullah/20 10/10/06/10643/menghafal-alqurandapat-tingkatkan-prestasi-

akademis/http://journal.student.uny.ac id/jurnal/artikel/8732/46/908 diakses 08/02/2017 jam 11:46

Hudoyo, Herman. (1998) Strategi Belajar Mengajar. Bandung : Remaja Rosda Karya.

Ibn Manzur (2003). Lisan Al-Arab. Cairo : Dar Shodir

Ibrahim, Anis. (1972) al-Mu'jam al-Wasieth. Mathabi' Darul Ma'arif.

Izzudin (2013). Efektivitas Penggunaan Media Pembelajaran Video Interaktif untuk Meningkatkan Hasil Belajar Praktik Service Engine dan Komponen-Komponennya.Tesis.

Semarang: Universitas Semarang.

Keller, Jhon M. (1983). Intructionl Design Therories and Models: An Overvieu of Their current Status, ed. Chrles M. ReGeluth. London: Lowrence Enbaum Associates, Publishers.

Khalid. (2008). Mengapa Saya Menghafal Qur'an. Solo: Daar An-Naba.

Khodijah, Nyayu (2014). Psikologi Pendidikan. Jakarta: PT Grafindo Persada.

Komara, E. (2014). Belajar dan Pembelajaran Interaktif.Bandung: PT. Refika Aditama. Kinetik Gas Untuk Meningkatkan Motivasi Belajar Fisika SIswa Kelas XI SMA Edisi 3. Volume 3. No. 8 Agustus 2014. 
Dede Ishak ${ }^{1}$, Uman Suherman ${ }^{2}$, Maskur $^{3 /} /$ Efektivitas Penggunaan Media Pembelajaran I-Spring Presenter Untuk Meningkatkan Kemampuan Tahfizh Al-Qur'an Di Pesantren Persis Tarogong

Kompri. (2015). Motivasi Pembelajaran Perspektif Guru dan Siswa. Bandun: PT. Remaja Rosdakarya.

Kusni. (2012) Peningkatan Motivasi dan Prestasi Belajar Pendidikan Agama Islam (PAI) melalui Penggunaan Media AudioVisual Siswa.Tesis.Walisongo : IAIN.

Kustandi, dkk. (2011). Media Pembelajaran. Bogor: Ghalia Indonesia.

Lazarus, Richard S (1961). Paterns of Adjusment. Third Edition.

Lutfi, A. (2009), Pembelajaran AlQur'an dan Hadits. Jakarta: Dirjen Pendidikan Islam.

Margono. (2010). Metodologi Penelitian Pendidikan, Jakarta: PT. Rineka Cipta.

Martiningtyas (2012). Pengertian Multimedia Interaktif. Jakarta: Ghalia Indonesia.

Novitasari (2015). Penerapan Multimedia Interaktif Berbanuan Perangkat Lunak iSpring Presenter Untuk Meningkatkan Motivasi Belajar Siswa dan Kemampuan Pemahaman Matematika Pada Mata Pelajaran Matematika Pokok Bahasan Geometri di Kelas X SMAN 6 Garut.Tesis. Garut: STKIP.

Nurjanah (2016). Modul I-Spring Presenter .pdf. http://teninurjanah2016.blogspot .com/2016/03/springpesenter...html? $\mathrm{m}=1$

Nurlaela (2016) Efektivitas Penggunaan Multimedia Pembelajaran Interaktif Melalui Pendekatan CTL Dalam Meningkatkan Hasil Belajar Peserta didik tentang Pesawat Sederhana pada Pembelajaran IPA di Kelas V Sekolah Dasar Negeri Cihanjuang. Bandung: Kaifa Learning
Rauf (2014). Pedoman Dauroh Alqur'an kajian ilmu Tajwid disusun secara aplikatif. Jakarta: Markaz Al-Qur'an. Rashid, Misyari (2019). https://islamdownload.net/124158murottal-misyari-rasyid-misharyrashid.html

Ridwan, W. (2011). Pengaruh Penggunaan Media Elektronik dalam Pembelajaran Akuntansi terhadap Peningkatan Prestasi Belajar Siswa.Tesis. Garut: STKIP.

Rogayah, I. (2011). Model Pembelajaran Berbasis Multimedia pada Tahfidz. (Hafalan) Al- Qur'an.Tesis. Garut: STKIP.

Ruseffendi, E. T. (1988). Penelitian Pendidikan dan Hasil Belajar Siswa. Khususnya dalam Pengajaran Matematika. Bandung: Tarsito

Sa'dullah (2010) Cara Praktis Menghafal AlQur'an. Jakarta : Gema Insani.

Sanjaya, W. (2015). Perencanaan dan Desain Sistem Pembelajaran. Jakarta: Prenadamedia Group.

Singgih, S. (2014). Statistik Parametrik. Jakarta: PT. Elex Media Komputindo.

Sudjana, Nana (2014). Penelitian Pendidikan-Jenis, Metode dan Prosedur. Jakarta: Prenadamedia Group.

(2000). Dasar Proses Belajar Mengajar. Bandung: Sinar Baru Algesindo.

Sundayana, R (2010). Statistika Penilaian Pendidikan. Garut : STKIP Press. (2014). Statistika Penelitian Pendidikan. Bandung: Alfabeta.

Surya, M .(2015). Strategi Kognitif dalam Proses Pembelajaran. Bandung: CV. Alfabeta (2014). Psikologi Guru-Konsep dan Aplikasi.Bandung: CV. Alfabeta.

Syah, Muhibbin (2010), Psikologi Pendidikan dengan Pendekatan Baru, Bandung: Remaja Rosda Karya.

Tasker, R (1992). Effective Teaching : What can a Constructivist View of Learning Offer. The Australian Science Teacher Journal. 
Dede Ishak ${ }^{1}$, Uman Suherman ${ }^{2}$, Maskur $^{3 /} /$ Efektivitas Penggunaan Media Pembelajaran I-Spring Presenter Untuk Meningkatkan Kemampuan Tahfizh Al-Qur'an Di Pesantren Persis Tarogong

Tati (2013). Efektivitas Model Pembelajaran CTL dalam Meningkatkan Prestasi dan Aktivitas Belajar Siswa pada Pelajaran IPS di Kelas VIII SMP Negeri I Bungbulang. Tesis. Garut: STKIP.

Taylor (1993). Dasar-Dasar Penelitian Kualitatif. Surabaya : Usaha nasional.

Wahyudin (2105). Statistika Terapan. Bandung: Penerbit Mandiri.

Warsita, Bambang (2008). Teknologi Pembelajaran, Landasan dan Aplikasinya. Jakarta : Rineka Cipta. 